\title{
Livestock production systems in the marginal upland and lowland areas of Inopacan Leyte, Eastern Visayas, Philippines
}

\author{
Warren D. Come and Philippine Dianne Zamora \\ Department of Animal Science, College of Agriculture and Food Science, Visayas \\ State University, Visca, Baybay City, Leyte.Philippines
}

\begin{abstract}
The study was conducted to obtain a baseline data of different livestock production systems, vegetation survey and animal environment interactions in the marginal upland in Eastern Visayas. A total of 280 farmer respondents were interviewed using an interview questionnaire. Vegetation species were gathered and validated with its genus and species group. Animal environment interactions particularly with chicken were also assessed. Results showed that chickens were the dominant species present in the study sites compared to other species. But in terms of total livestock units (TLU), buffaloes have higher TLU compared to other species of animals. Farmer's income is mostly from the agricultural income with less than $20 \%$ of agricultural income was obtained from livestock farming. Livestock only serves as buffer income incase crops will fail. Different husbandry systems are used by the farmers such as free range system for chicken, ducks and turkeys while pigs are raised in confinement or caged system. Ruminant productions are raised in a tethering system of production. Natural breeding practice is still practiced by farmers and traditional animal health practices are still evident in this marginal upland. Ruminants graze in different vegetation diversity in grasslands and under the coconut trees. Likewise, plant residues of banana, coconut and root crops are also used as feed resources of farmer respondents. Grass and herb species that are palatable to the animals are diverse also especially in grassland areas. Availability of feed resources in the area plays a crucial role also on how animals interact with the environment and may affect also with their feeding behavior when there are changes in the climatic conditions. Preliminary result of the study on animal environment interaction shows that chickens tend to change their feeding itineraries due to availability of feed resources, environmental temperature and rainfall.
\end{abstract}

Keywords: livestock production systems, vegetation, animal-environment interactions, marginal uplands, traditional animal health

Correspondence: W.D. Come Address: Department of Animal Science, College of Agriculture and Food Science, Visayas State University, Visca, Baybay City,Leyte.Philippines Email:wdcome@gmail.com DOI: 10.32945/atr36s 14.2014 


\section{INTRODUCTION}

The Philippines has a total land area of 30 million hectares. Out of the country's land area, an estimated 14.9 million hectares are classified as uplands. An area is considered upland if it has a slope ranging from 18 percent upward. Upland areas generally encompass grassland and forest ecosystems. They are important support systems of the upstreamdownstream continuum, giving life to the lowland and coastal ecosystems. On the socio-economic aspect, upland areas have been characterized to have a rapid increase in population. Farming could be described as dependent on rainfall, with limited infrastructures, lacking in effective marketing systems, and having almost no credit and financing structures. Employment for farmers is seasonal, earning them meager income.

Livestock production in marginal uplands plays an important role to the inhabitants as a source of income, food and maintains traditional practices. Livestock management practices in the marginal upland areas are diverse in terms of type of animals raised, animal health practices, feeding and feed resources, pasture management, available pasture forages and others. Evaluation of these particular livestock husbandry practices is important to have a baseline data and information on the traditional and present management practices of the farmers in rearing livestock. Baseline data will be used as basis in the implementation and improvement of the livestock production systems in the marginal uplands.

The study was conducted to acquire baseline data on the livestock husbandry practices and pasture vegetation in the selected marginal uplands. It assessed the existing and traditional livestock husbandry practices; the pasture area and the existing plants and forages present in the identified areas; and the animal- environment interactions of animals with existing environmental and climatic conditions.

\section{METHODOLOGY}

\section{Study site selection}

The study was conducted in different barangays of Inopacan, Leyte Philippines. The area was selected based on the characteristics of marginal uplands. There were six barangays that were included in the study namely, Linao, Guinsanga-an, Mara-o, Hinabay, Caminto and Cabulisan. Selection of the villages was done based on the following criteria: (1) accessible to 
communication and transportation, (2) local government officials and barangay officials as well as the farmers are willing to cooperate and (3) livestock is part of the farming system practiced in the study area.

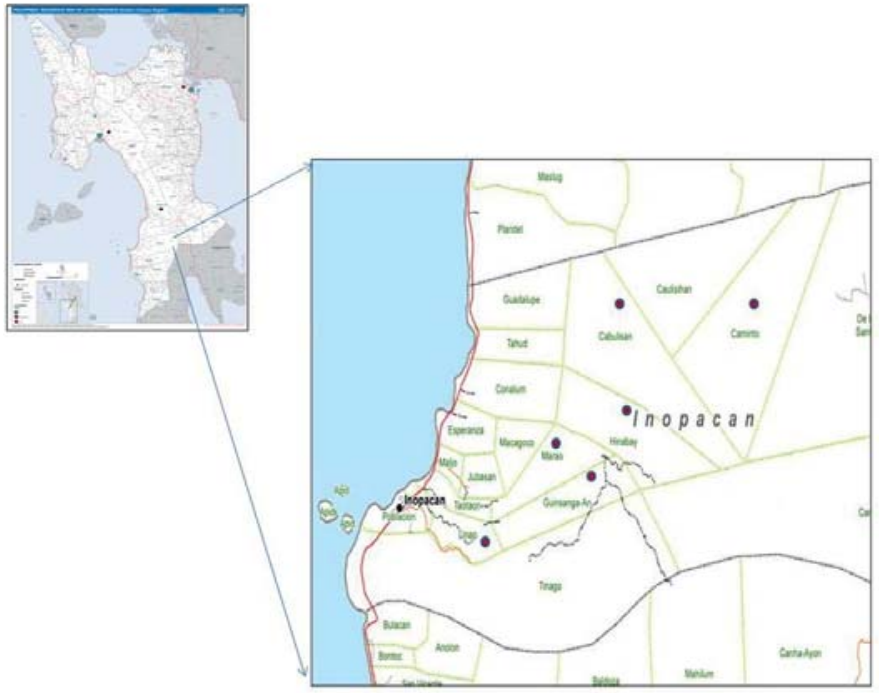

Figure 1. Location map of the different study sites.

Study Sampling Procedure

To gather information and data related to livestock husbandry systems such as productivity, feed type, feed resources, animal health and breeding, a survey was conducted in the selected villages. A total of 280 respondents were randomly selected to serve as respondents of the study. Recent list of all the farmers in the selected barangays were obtained from the Municipal Agricultural office, Local Government Unit. The number of respondents was obtained based on the formula in getting the population size at 95\% confidence level and 5\% confidence interval.

Focus group discussion (FGD) was also conducted to facilitate in the creation of interview schedule. Livestock raisers, local government officials and livestock technicians were the participants of the FGD. 


\section{Questionnaire Preparation}

A pre-formatted interview questionnaire guide was edited based on some results of the focus group discussion. Questions were directed on to the needed information regarding livestock husbandry systems in the marginal uplands. The questionnaire consists of the following questions: socio-demographic characteristics of the respondents; farmers livestock production practices; livestock systems used; feed and feed resources, pasture vegetation, animal health practices, breeding and opportunities and constraints in livestock production.

The questionnaire which was written in English was translated to Visayan dialect for better understanding of the respondents. Before the actual interview, a pre-test of the questionnaire was done in the different selected sites. Results of the pre- test of questionnaire were used to edit the interview instrument.

\section{Data Collection}

Hired enumerators together with the research assistant were properly trained on how to conduct proper interviews with the farmers before assigning them to the field. Before conducting the interview, the research assistant together with the enumerators asked permission from the barangay captain to conduct the research in the study site. A public forum with the community was conducted to inform the people about the research. During the forum the study leader explain about the objectives and goals of the study. After getting the permission from local leaders as well as the community, the enumerators conducted personal house-tohouse interview with the selected respondents.

\section{Vegetation Survey}

A rapid vegetation survey was conducted in different grazing areas of the six villages. Transect method was used to classify vegetation types. Brown-Blanquet Method was used in the assessment of the vegetation of the grazing areas. Individual plants commonly grazed by livestock were collected during the survey and was identified with the help of the farmers and confirmation from biodiversity experts. Vegetation survey data from other project in the same site was also accessed for a harmonized characterization of the different vegetation types present in the study area. 


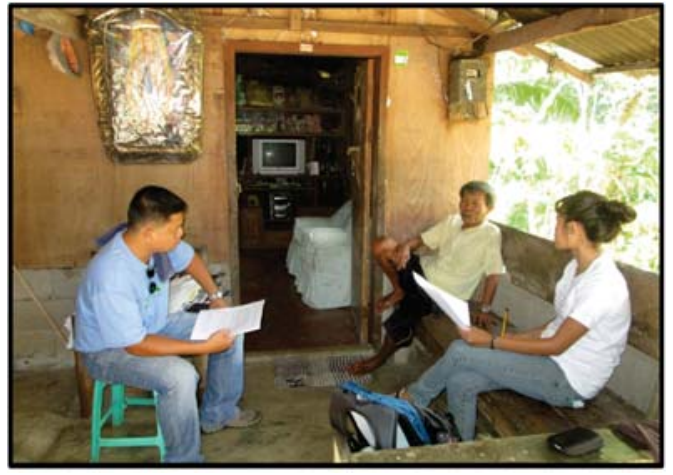

Figure 2. Interview of the farmer cooperators

Animal-Environment Interaction Survey (Chicken)

After a preliminary analysis of the interview data, it shows that $90 \%$ of the respondents raised native chicken for different purposes. The conduct of this survey was focused on one single species of livestock due to time constraints, environmental conditions and availability of equipment. A student researcher for his undergraduate thesis conducted the said survey on animal- environment interactions.

\section{Data Analysis}

To describe data on the outcome of the interview questionnaire, descriptive statistics such as frequency, percentages and totals were used. On the other hand, vegetation data survey was interpreted using narrative descriptions.

Data on animal environment interaction survey was analyzed using Paired T-test statistical analysis and Microsoft Office Exel 2010.

\section{RESULTS AND DISCUSSION}

\section{Profile of respondents}

Education Level. Of the 280 respondents, $58.2 \%$ reach the elementary level and $37.9 \%$ reach the secondary level of education. College level and college graduate have $2.1 \%$ and $1.4 \%$ respectively. Likewise, there was less than $1 \%$ of the respondent with vocational education. All respondents were male as the target respondents were the male head of the family. Age 
Livestock production systems in the marginal upland and lowland areas

level of the respondents falls in the bracket range from 35-75 years old. The youngest respondent was aged 35 while the oldest was aged 75. Majority of the respondent's age was on the range between 45-60 years old.

Farmers Income. Of the 280 farmer respondents, 77\% agreed that $100 \%$ of their income come from agriculture. Proportional ratio of 60:40 $\%$ and $80-20 \%$ agricultural: nonagricultural income had $6 \%$ both of the farmer respondents.

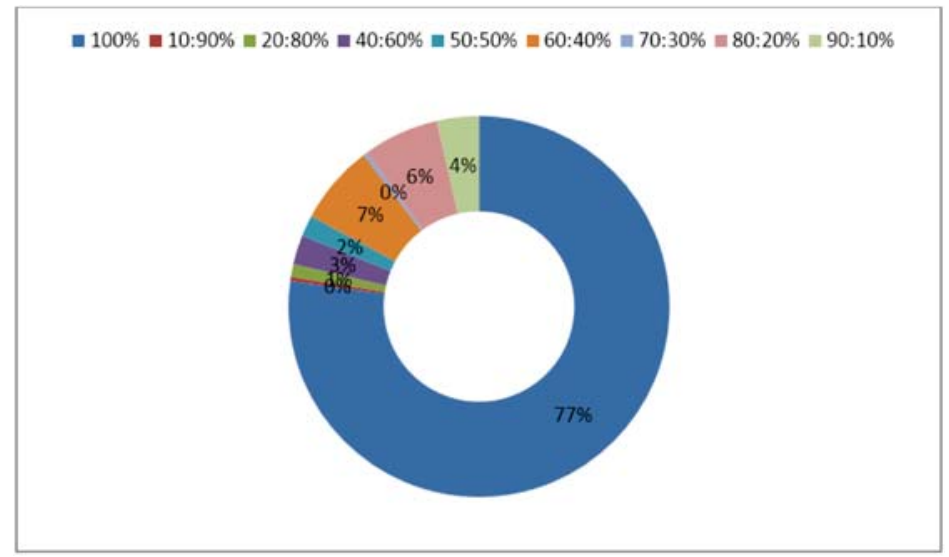

Figure 3. Percent proportion of agricultural- non-agricultural income

Non Agricultural income. There were 78\% of the total respondents that has no income coming from agriculture related work. Other nonagricultural income of respondents was government employees, security guards, carpenters and laborers. Likewise, some of the respondents were business minded in establishing small stores in the village or "sari-sari store" and selling native foods in the community like cooked vegetables and cooked vain. Others asked financial support from relatives and family members and the rest uses their talents and skills to acquire income such as cook, mechanic, sewer, and barber. Other non-agricultural income is stated in Table 1. 
Table 1. List of sources of non-agricultural income of farmer respondents.

\begin{tabular}{lc}
\hline None Agricultural Income & Percentage \\
\hline Carpenter & 2.5 \\
Cook & 0.4 \\
financial support from family member & 2.1 \\
Government employee & 3.6 \\
Motorcycle driver & 1.4 \\
house rental income & 0.4 \\
Laborer & 0.4 \\
mat weaving & 0.4 \\
Nanny & 0.7 \\
None & 78.2 \\
Pensioner & 0.4 \\
sari sari store owner & 6.4 \\
security guard & 0.7 \\
Sewer & 0.4 \\
Barber & 0.4 \\
selling native foods & 1.4 \\
Mechanic & 0.4 \\
\hline Total & 100.0 \\
\hline
\end{tabular}

Proportion of livestock income. Livestock income is only a small proportion of the total agricultural related income of the farmer respondents. Majority of the farmer respondents (70\%) said that their livestock income is only $10-20 \%$ from their agricultural income. While $20 \%$ of the farmer respondents have $30-40 \%$ proportion of livestock income and the remaining $10 \%$ of farmers have above $50 \%$ proportion of livestock income. Farmers mostly concentrate on annual crops and vegetable production. Livestock only serves as savings for future use when crops fail to deliver income to the household.

\section{Livestock Population}

Chicken ranks first in terms of population in the area. More than 4000 heads of chicken were recorded from the farmer respondents. These chickens are a combination of native free range chicken and fighting cocks. Of the total population, only $10 \%$ constitutes with the fighting cock population. Of all the livestock species present in the area, chickens are the 
Livestock production systems in the marginal upland and lowland areas

most populous since chickens can be easily acquired, they reproduce in a short period of time, can be raised with minimal supervision and by tradition native chickens are commonly raised by farmers in the marginal uplands according to farmer respondents. Highest number of heads of chicken raised by a single farmer was 64 while the lowest is 3 heads.

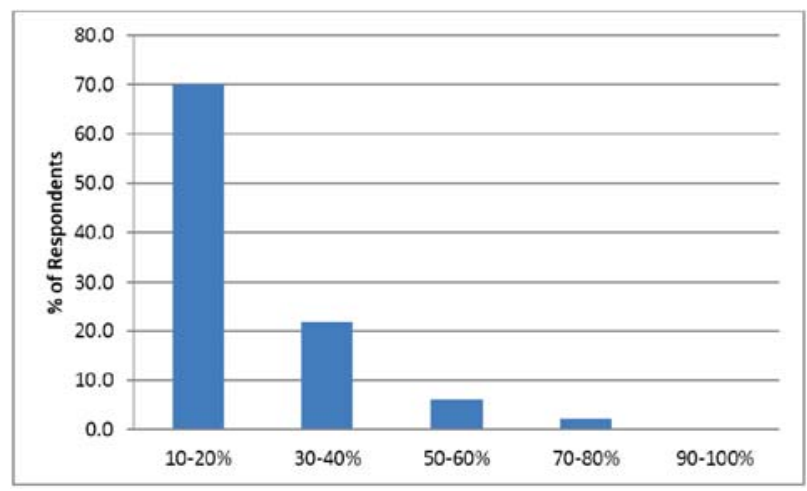

Figure 4. Percent proportion of livestock income from agricultural income

Next in rank to the chickens in terms of population are swine and goats. More than a hundred heads are raised both for goat and swine. Swine raised in the area are natives pigs and upgraded breeds of swine. Less than a hundred heads were recorded for buffalo and cattle. Buffaloes are raised mainly for draught power used for agricultural related activities. On the other hand, cattle are raised for savings purposes with less minimal supervision and maintenance. Other species of livestock raised in the study area are ducks, turkeys and horses.

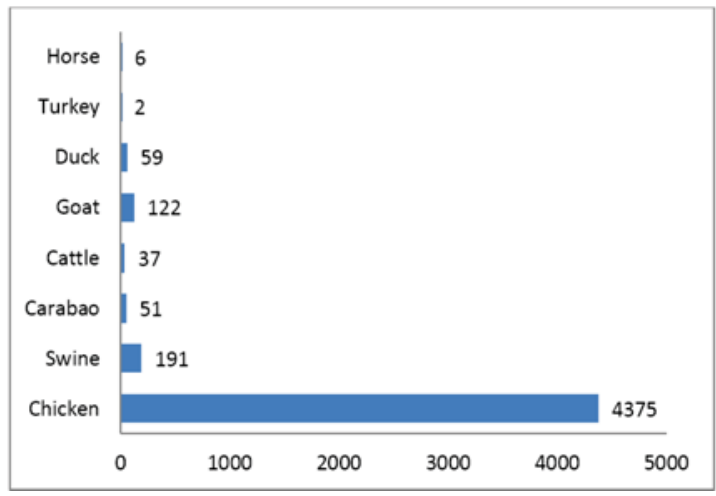

Figure 5. Number of heads of different species of livestock 


\section{Total Livestock Unit}

Total livestock unit are used to evenly compare the population of livestock in a particular area in terms of the body weight of the animals. For every one total livestock unit (TLU) is equivalent to 250 kilograms. Approximation of the body weight of the animals was done during the survey. In the analysis it comes out that carabaos or buffaloes have the highest total livestock unit among other livestock species. Chickens have less total livestock unit compared to swine, cattle and buffalo since they have less body weight compare to the other species present in the study sites.

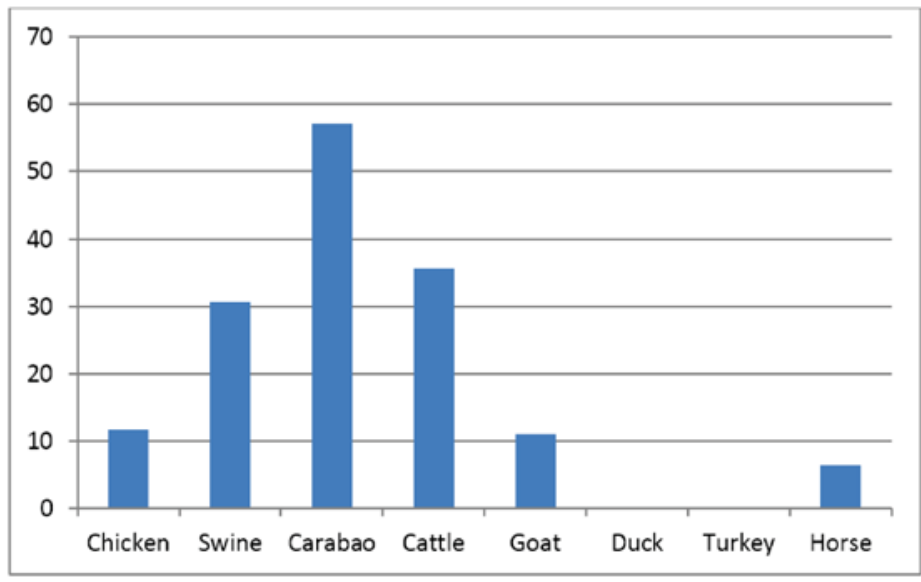

Figure 6. Total livestock unit of different species of animals (1TLU=250kgs BW)

\section{Method of Keeping Livestock}

\section{Poultry Production System}

Half of the farmer respondents up to $52 \%$ practiced free range system of raising chicken while $30 \%$ percent practiced the combination of free range and caged system. Some farmers (10\%) practiced solely with caged system and less than $1 \%$ practiced corralled and a combination of corralled plus free range system of raising chicken. With ducks, they are raised in a corralled system or a combination of corralled and free range system. There were two farmer respondents that raise turkey in a corralled type of production system. 
Livestock production systems in the marginal upland and lowland areas

\section{Swine Production System}

Pigs are commonly caged as observed by the researchers and some are tethered especially the native pigs rose in the upland areas. Most commonly caged breed were the upgraded type of pigs since they cannot stand outdoors during harsh weather or changing weather conditions.

\section{Ruminant Production System}

Buffaloes and cattle are mostly tethered under the coconut trees. Free range are only allowed once the animal is still your or not yet weaned from the mother. Once the calf is weaned already, it is tethered then. For goats, farmers practice tethering system since goat can be destructive to crops if allowed to roam around freely. There are also farmers practiced a combination of free range- tethering system and corralling of goats. Corralling system of goats was practiced also by two respondents.

\section{Horse Production System}

There were three farmer respondents who raise horses in a tethering way. Horses were raised for its draught power purposes especially in carrying heavy loads of agricultural products in the upland area. Horses are tethered in the vegetation's under the coconut trees.

\section{Sources of Livestock}

Majority of farmers acquire their livestock by purchasing the animal (32.7\%). This applies to all types of livestock raised by farmers. They purchased the animals from their neighbors, other municipalities or from other sources of breeder animals. Some animals were source out from their own breeds (21.6\%). "Alima" system (21.6\%) is another way of acquiring breeder animals. This is more practiced with ruminant animals such as buffalo, cattle and goats. Farmers will borrow and take care a breeder female animal and once the animal gave birth, the first offspring will be given to the person who took care of the animal and the next offspring is given to the owner of the breeder. The lender of the breeder still has the full right of the breeder animal. Some breeders were given to the farmers by friends, relatives and from the local government unit as a dispersal program. There are also farmers who inherited $(9.3 \%)$ their breeder stocks particularly from their parents as a gift. 
Table 2. List of different production systems and method of keeping of different species of animals

\begin{tabular}{|c|c|c|c|}
\hline Species & & Total & Percentage \\
\hline \multicolumn{4}{|l|}{ Chicken } \\
\hline Free Range & & 146 & 52.1 \\
\hline Free Range + Caged & & 86 & 30.7 \\
\hline Caged & & 29 & 10.4 \\
\hline Corralled & & 9 & 3.2 \\
\hline Corralled + Free Range & & 1 & 0.4 \\
\hline \multirow{2}{*}{ None } & & 9 & 3.2 \\
\hline & Total & 280 & 100.0 \\
\hline \multicolumn{4}{|l|}{ Buffalo } \\
\hline Free Range & & 1 & 0.4 \\
\hline Tethered & & 38 & 13.6 \\
\hline Free Range + Tethered & & 3 & 1.1 \\
\hline \multirow[t]{2}{*}{ None } & & 238 & 85.0 \\
\hline & Total & 280 & 100.0 \\
\hline \multicolumn{4}{|l|}{ Cattle } \\
\hline Tethered & & 21 & 7.5 \\
\hline \multirow[t]{2}{*}{ None } & & 259 & 92.5 \\
\hline & Total & 280 & 100 \\
\hline \multicolumn{4}{|l|}{ Swine } \\
\hline Free Range & & 1 & 0.36 \\
\hline Tethered & & 1 & 0.36 \\
\hline Caged & & 47 & 16.79 \\
\hline Caged + Corralled & & 2 & 0.71 \\
\hline Corralled & & 3 & 1.07 \\
\hline \multirow[t]{2}{*}{ None } & & 226 & 80.71 \\
\hline & Total & 280 & 100.00 \\
\hline \multicolumn{4}{|l|}{ Goats } \\
\hline Free Range & & 3 & 1.1 \\
\hline Tethered & & 37 & 13.2 \\
\hline Caged & & 2 & 0.7 \\
\hline Tethered + Free Range & & 1 & 0.4 \\
\hline Corralled & & 2 & 0.7 \\
\hline \multirow[t]{2}{*}{ None } & & 235 & 83.9 \\
\hline & Total & 280 & 100.0 \\
\hline \multicolumn{4}{|l|}{ Ducks } \\
\hline Free Range & & 5 & 1.8 \\
\hline Corralled + Free Range & & 1 & 0.4 \\
\hline \multirow[t]{2}{*}{ None } & & 274 & 97.9 \\
\hline & Total & 280 & 100.0 \\
\hline \multicolumn{4}{|l|}{ Horse } \\
\hline Tethered & & 3 & 1.1 \\
\hline \multirow{2}{*}{ None } & & 277 & 98.9 \\
\hline & Total & 280 & 100.0 \\
\hline
\end{tabular}


Livestock production systems in the marginal upland and lowland areas

Table 3. Different sources or mode of acquisition of livestock

\begin{tabular}{lc}
\hline \multicolumn{1}{c}{ Source of Livestock } & Percentage \\
\hline Alima System & 21.6 \\
Inherited from parents & 9.3 \\
Given & 14.8 \\
Own Breeding & 21.6 \\
Purchased & 32.7 \\
\hline Total & 100 \\
\hline
\end{tabular}

Breeding System

Breeding practices applies by farmers to all species of animals is the natural method. Up to $98 \%$ of the farmer respondents still use the natural way of breeding livestock. Less than $2 \%$ of farmers practice artificial insemination (AI) particularly with swine. These farmers who practice swine artificial insemination has advance technical knowledge regarding AI by attending seminars and trainings conducted by the Department of Agriculture-LGU or seminars sponsored by private companies.

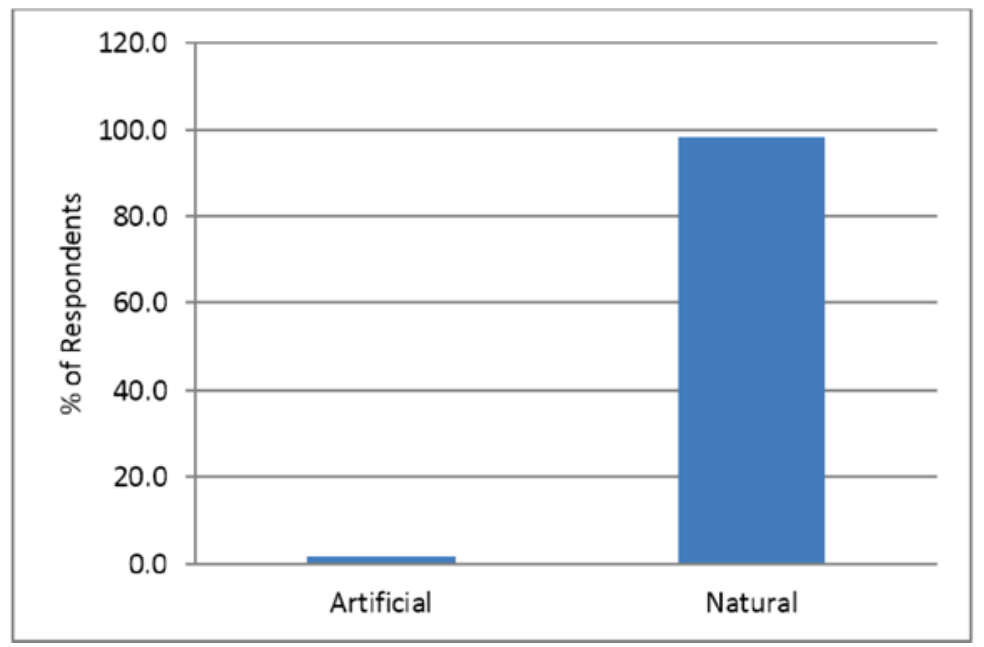

Figure 7. Breeding methods used by the farmer respondents

\section{Animal Health Practices}

There were two categories of animal health practices most commonly practiced by farmers in the marginal uplands. Most of these are traditional 
animal health practices since conventional methods are not accessible and commercial drugs are expensive according to the farmers. Traditional practices are the plant based animal health management and the animal based health management. Ninety percent (90\%) of the farmer respondents rely on plants to manage health problems of their livestock. The remaining $20 \%$ of farmers combine plant based and animal based practices.

\section{Plant based animal health practice}

A total of nineteen (19) livestock ailments were document which are common health problems in the uplands. New Castle Disease and fowl pox are the most common diseases that occur in chickens. On the other hand, scouring and vomiting were reported also in swine and ruminants. There were seventeen (17) plant species that were identified by farmers which they use to treat ailments of livestock. Leaves and fruit part of the plant were commonly used directly to animals. Some plant parts were processed like concoction, decoction, and extraction of liquid part of the plant and plant parts directly given to animals. Oral administration is the common method of administration of medicinal parts. Listed in table 4 are the different plant species used by farmers with their local names and scientific names.

\section{Animal based health practice}

Few farmers still use the traditional way of prevention and treatment of animal diseases. Farmers practice pinning of tail feather on the dorsal part of the chicken neck in order to prevent animal from acquiring the disease particularly New Castle Disease and Fowl pox. Likewise, farmers also practice introduction of "patani" breed of chicken to the flock in order to prevent flock from contracting any disease. One farmer also traditionally practice treating chicken ailments by heating the digit part of "Banog" commonly known as Philippine Eagle (Pithecophaga jefferyi) mix it with oil and applied at the back part of the chicken. These ethno- veterinary practices may sound unusual but still being practiced in the marginal uplands.

Plant based and animal based traditional practices still exist in Inopacan, Leyte. Further research including plant tissue analysis and experimental trials to livestock may be conducted to support the effectiveness of these practices. 
Livestock production systems in the marginal upland and lowland areas

Table 4. List of plants used by farmers for traditional animal health practices

\begin{tabular}{|c|c|c|c|c|}
\hline Local Name & Scientific name & $\begin{array}{l}\text { Disease/Symptomatic } \\
\text { Treatment }\end{array}$ & $\begin{array}{l}\text { Plant } \\
\text { part }\end{array}$ & $\begin{array}{l}\text { Livestock } \\
\text { species }\end{array}$ \\
\hline Panyawan & $\begin{array}{l}\text { Tinospora } \\
\text { rumphiii }\end{array}$ & $\begin{array}{l}\text { New Castle Disease } \\
\text { (NCD) }\end{array}$ & Vine & Chicken \\
\hline Sili & $\begin{array}{l}\text { Capsicum } \\
\text { frutescens }\end{array}$ & Fowl pox, NCD, flu & Fruit & Chicken \\
\hline Nangka & $\begin{array}{l}\text { Artocarpus } \\
\text { heterophyllus }\end{array}$ & Scouring & leaf & Pig, goat \\
\hline Ampalaya & $\begin{array}{l}\text { Momordica } \\
\text { chanrantia }\end{array}$ & $\begin{array}{l}\text { Cough, flu, weak, in } \\
\text { appetence }\end{array}$ & leaf & Chicken \\
\hline Kalabo & Herba buena & $\begin{array}{l}\text { Dry cough, weak, } \\
\text { respiratory disorders, } \\
\text { NCD }\end{array}$ & leaf & Chicken \\
\hline Ajos & Allium sativum & NCD & Bulb & Chicken \\
\hline Latundan & Musa paradisiac & $\begin{array}{l}\text { Scouring, weak, } \\
\text { vomiting }\end{array}$ & Leaf & Pig, Carabao \\
\hline Lobi & Cocos nucifera & $\begin{array}{l}\text { Poisoning, sudden } \\
\text { death }\end{array}$ & Fruit(oil) & Chicken \\
\hline Agasi & $\begin{array}{l}\text { Leucosyke } \\
\text { capitellata }\end{array}$ & $\begin{array}{l}\text { Diarrhoea, weak, in } \\
\text { appetence }\end{array}$ & Leaf & Chicken \\
\hline Lagnob & Ficus septica & Arthritis, weak & Leaf & Pig \\
\hline Lobi-lobi & Adonidia merrilli & $\begin{array}{l}\text { Flu, cough, weak, } \\
\text { emaciated, NCD }\end{array}$ & Fruit & Chicken \\
\hline Paminta & Piper nigrum & Weak, bloated face & Seed & Chicken \\
\hline Mansanitas & Ziziphus jujube & Scouring & Leaf & Pig, goat \\
\hline Bayabas & Psidium guajava & Respiratory disorders & Leaf & Chicken \\
\hline Tugas & Vitex parviflora & Coughing & Bark & Chicken \\
\hline Malunggay & Moringa oleifera & NCD & leaf & Chicken \\
\hline Hagupit & To be indetified & $\begin{array}{l}\text { Open wounds, } \\
\text { injuries, dog bites }\end{array}$ & leaf & Carabao, goat \\
\hline
\end{tabular}

Table 5. Animal based ethno-veterinary practices adopted by the farmers

\begin{tabular}{ll}
\hline Disease/Symptoms & Ethno-veterinary practice \\
\hline $\begin{array}{l}\text { NCD, Fowl pox, in } \\
\text { empetence, weakness, }\end{array}$ & $\begin{array}{l}\text { Pinning of tail feather on the dorsal part of chicken neck } \\
\text { for prevention of the disease. }\end{array}$ \\
\hline NCD, Fowl pox & $\begin{array}{l}\text { Introduction of "Patani", a chicken breed in the flock to } \\
\text { prevent diseases. }\end{array}$ \\
\hline NCD & $\begin{array}{l}\text { Heating the digit part of "Banog" commonly known as } \\
\text { Philippine Eagle (Pithecophaga jefferyi) and mixed with } \\
\text { oil and apply on the back of the chicken for treatment }\end{array}$ \\
\hline
\end{tabular}




\section{Vegetation Survey}

Several plants and vegetation's were surveyed as a potential for feed resources which can be edible to livestock. During the interview, farmers were asked on different plants and plant residues which they feed to their livestock. Banana leaves are used as feed given to pigs fresh while the trunk of banana is cooked and given also to the pigs. Coconut meat is also given to pigs and chicken. Coconut meat extracted with its coconut milk is given to chickens as plant residue. On the other hand, rice straw a plant residue is given to buffaloes and cattle especially during dry season. Root crop like cassava and sweet potato are also given raw to pigs while jackfruit leave are given also to pigs as feed supplement. Ipil-ipil is given to swine, cattle, goat and buffalo.

Table 6. List of plant species used as feed resources for livestock feeding

\begin{tabular}{ll}
\hline Common Name & Scinetific Name \\
\hline Banana & Musa acuminata \\
Coconut & Cocus nucifera \\
Rice Straw & Oryza sativa \\
Ipil-ipil & Leucaena leucocephala \\
Jackfruit & Artocarpus heterophylus \\
Corn & Zea maize \\
Cassava & Manihot iscolenta \\
Sweet Potato & Ipomoea batatas \\
\hline
\end{tabular}

Other plant species of grasses which are common in grassland and in shaded areas in marginal uplands were also assessed. Diverse species were found which are palatable and nutritious particularly with ruminant animals. Some of the plant species listed in Table 7 was adopted from other Project 1 where they surveyed on biodiversity of grassland areas commonly used as pasture areas of ruminant animals.

\section{Animal-Environment Interaction Survey (Chicken)}

A survey of the spatial and temporal differences of feeding behavior of native chickens in the marginal uplands as affected by feeding time and environmental factors were conducted. Due to equipment delay and unusual environmental conditions, the activity was only conducted 
Livestock production systems in the marginal upland and lowland areas

last May to June 2014. Data collected are still on the process of analysis and interpretation.

Preliminary results showed that chickens can walk up to two hectares of distance in the whole day just for searching for food. This depends on the condition of the surroundings and affected also by temperature, flock grouping and rainfall. Spatial and temporal differences were also observed depending on the age, feeding behavior, environmental temperature and amount of rainfall. Availability also of external feed resources given to chicken affects also it spatial and temporal feeding itineraries.

Table 7. List of common grasses and herbs present in the pasture and grassland areas

\begin{tabular}{ll}
\hline Common Name & \multicolumn{1}{c}{ Scientific Name } \\
\hline Cogon & Imperata cylindrica \\
Hantotoknaw & Melastoma malabathricum \\
Hagonoy & Chromolaema odorata \\
Malagabon & Elephantopus specatus \\
Mani-mani & Desmodium triflorum \\
Fern & Neptirolepis tirsutula \\
Daat & Scleria sphaecocarpa \\
Carabao grass & Paspalum conjugatum \\
Baryo-baryo & Piper aduricum \\
Makahiya & Mimosa pudica \\
Dysmodium & Desmodium ovaliforium \\
Bugang/Talahib & Saccharum spontaneum \\
Cotton-cotton & Desmodium ovaliforium \\
Malagabon & Elephantopus tomentosus \\
Gabon & Blumea balsamifera \\
Alibangbang & Piliostigma sp. \\
Malacogon & for confirmation \\
Mini-mani mani & Alysicarpus sp. \\
Kadena de Amor & for confirmation \\
Amorseco & Chrysopogon aciculatus \\
Bukot-bukot & Centella sp. \\
Unidentified grass & \\
\hline
\end{tabular}




\section{SUMMARY AND CONCLUSIONS}

This study was conducted to assess the livestock production systems, productivity, feed resources and animal-environment interactions of livestock in the marginal upland in Inopacan Leyte. The main objective of the study is to acquire a baseline data on the livestock production systems, vegetation survey and interactions of livestock to changing climatic conditions. A total of 280 farmer respondents (male/ head of the family) were randomly selected and interviewed using interview schedule in six selected barangays of Inopacan, Leyte.

Results showed that majority of the farmer respondents are elementary and secondary level of education. Family size of household mostly belongs to 4-6 bracket of number of family members with household income usually relies on agricultural commodities such as crop and livestock. Livestock income only constitute up to $20 \%$ as the highest proportion of income while $10 \%$ proportion of livestock income is the lowest. In terms of livestock population, chicken has the highest in numbers, but with the total livestock unit, large ruminant like buffalo and cattle has the highest.

Method of keeping of animals in the marginal uplands is considered extensive in terms of production system. Farmers mostly rely on resources present in the locality. Chicken production system, majority are free range and a combination of caged and free range. Pigs are mostly caged especially the upgraded breed while native breeds are tethered combined with free range. Ruminants are mostly tethered in the grassland areas or under the coconut trees. Livestock are acquired by purchase, "alima sytem" and from own breeding. Breeding system used in all livestock is natural breeding system.

On the other hand, vegetation survey revealed that vegetation in grassland areas and under shaded areas of coconut are well diverse in terms of the diversity of palatable plants for livestock particularly ruminants. Farmers also use crop residues to feed livestock.

Furthermore, livestock production systems in the marginal upland are vulnerable to climate change. With the preliminary results of animalenvironment interactions with chicken species, chickens tend to adapt to the daily change of climatic conditions. Feeding itineraries of chicken may be affected with changing environmental factors. Spatial and temporal itineraries of foraging native chickens are affected with temperature and rainfall patterns. 
Therefore, livestock production system in the marginal uplands should be given emphasis with research and extension so that livestock raisers in the marginal upland will be more resilient with climate change. Research should focus on suitability trails of different improved pasture grasses, animal environment interactions of different livestock species and validation of plant based and animal based traditional health management practices.

\section{ACKNOWLEDGMENT}

The study leader of Project 4 Study 1 expresses his great appreciation to the Commission on Higher Education through Philippine Higher Education Research Network for funding this study. To farmer cooperators of Brgys. Linao, Guinsangaan, Marao, Hinabay, Caminto and Cabulisan, Inopacan, Leyte for being cooperative during the interview. The Local Government unit of Inopacan, Leyte and Barangay officials for their support to this study.

\section{REFERENCES}

ARDESHIR B. 2012. Inheritance of Important Economic Traits in Chickens UnderShort Term Selection. INTERNATIONAL JOURNAL OF ANIMAL AND VETERINARY ADVANCES 4(2): 109-112, 2012

AVANTE, D.C.1989. The Performance of the Philippine Native Chicken and Other Breeds for Eggs and Meat in the Philippines. Food and Fertilizer Technology Center Extension Bulletin No. 290. Pp. 11-14.

BARKER,J.S.F. 1994. "Conservation and Management of Genetic Diversity." In Proceedings of the $5^{\text {th }}$ World Congress on GeneticsApplied to Livestock Production, Guelph, Ontario, Canada, 501-508.

BAS. 2004a. Duck industry performance report. January-December 2003. Livestock and Poultry Statistics Division, BAS, Department of Agriculture. June 2004 (available at http://www.bas.gov.ph/download _now.php?id=63). 
BAS. 2004b. Chicken industry performance report, January-December 2003. Livestock and Poultry Statistics Division, BAS, Department of Agriculture, June 2004 (available at http://www.bas.gov.ph/ download_now.php?id=62)

BONDOC, O.L.1998. Biodiversity of Livestock and Poultry Genetic Resources in the Philippines. IAS CA/UPLB and PCARRD DOST.

CASTELLA, C.,EGUIENTA, Y., C. MARTIN, P. LECOMTE, and O. HUSSON, J. (2002). Crop-livestock interactions in northern Viet Nam: Issues, diversity of farmers' responses, and alternatives for sustainable integration of animals in upland agricultural systems. International Rice Research Institute (IRRI), DAPO 7777, Metro Manila, Philippines.

CASTELLA, J. C. and DANG DINHQUANG eds. (2002).DoiMoi in the Mountains. Land use changes and farmers' livelihood strategies in BacKan Province, Vietnam. The Agricultural Publishing House, Ha Noi, Viet Nam. 221-247.

CASTILLO, E.T., and L.L. PINTOR. (2010). A RESEARCH COMPENDIUM FOR DAMAGED MARGINAL UPLANDS. Ecosystems Research and Development Bureau Department of Environment and Natural Resources College,

COME, W. D. (2011). Environmental effects of ruminant husbandry systems in the protected landscape and seascape area in Batanes, Philippines. Unpublished M.Sc. Dissertation. University of Kassel, Witzenhausen, Germany.

CHOPRAKARN, K., S. THAMMABUTR, and W. SURIYACHANTRATONG. (1983). Problems and Approach Relating to Improving of Thai Indigenous Chickens. In Proceedings of the First Seminar on Thai Indigenous Chickens, KhonKaen, Thailand Northeastern Regional Office of Agriculture. Journal of Poultry in the 21st (Vol. 4, p. 60â).

CHOPRAKARN, K., S. THAMMABUTR, N. UPPATUM, and W. SURIYACHANTRATONG. 1984. A study on survival rate and growth rate of Thai indigenous chickens. In Abstracts of the Animal Science Research, 22nd Annual Conference, Kasetsart University. Bangkok, Thailand. (original in Thai) 
Livestock production systems in the marginal upland and lowland areas

CRAWFORD, R.D. 1990.Poultry Breeding and Genetics. New York:Elsevier.

DEVENDRA C. and C.C. SEVILLA (2002) Availability and use of feed resources in crop-animal systems in Asia. Agricultural Systems, 71: 5973.

DAVID J. A., and D.D. JUSTIN. 2013. Assessing Herbivore Foraging Behavior with GPS Collars in Semiarid Grassland. Research

HUSSON O., J.C. CASTELLA, HA DINH TUAN and K. NAUDIN. (2001) Agronomic diagnosis and identification of factors limiting upland rice yield in mountainous areas of northern Vietnam. SAM Paper Series 2, Vietnam Agricultural Science Institute, Ha Noi, VietNam. 16 p.

HELVETAS (2000) Report of the Rapid Market Appraisal (RMA): Into Animal ProductsOriginating in Cao Bang Province. Helvetas, Ha Noi, Viet Nam.49 p.

FLORESCA W.F. 1998. Advanced Poultry Production. Baybay, Leyte: Center for Extramural Studies, Visca Open University

FOOD AND AGRICULTURE ORGANIZATION of the United Nations (FAO). 2003. Status of the Philippine Animal Genetic Resources: A Country Report. Rome, Italy: FAO.

KLINHOM, U., C. WONGSAMAN, S. KANHAREING, TREEMANEE, S. P. SUEKAEW, P.UTARASK and K. PIMDEE.2005. Native chicken production and management by using indigenous knowledge in the northeast of Thailand. Technical report submitted to Thailand Research Fund. 70 pp. (original in Thai, English abstract).

LAMBIO A.L. 2010. Poultry production in the tropics. In "Production in Native Chiken and Other Poultry Species", Quezon City: The University of the Philippines,c2010

LAMBIO, A.L. 2005. "The Future Prospects for Smallholder Native Chicken Producers in the Philippines". ElpidioQuirino Professorial Chair Lecture. 24 June 2005. ADSC Lecture Hall, UPLB-CA. 
LAMBIO, A. L., M. C. GRECIA, and A. P. AMADO 2000. Comparative evaluation of the carcass and sensory characteristics of four genetic group of the Philippine native chicken. Philippine Journal of Veterinary and Animal Sciences 26: 129-36.

LAMBIO, A.L. 2000. "Germplasm and New Breeds of the Philippine Native Chickens." The Philippine Agricultural Scientist 83 (1): 12-117.

MANLEON, A.M., and A.A. BARRION. 2002. "Evolutionary Genetics of the Philippine Native Chickens." Animal Husbandry and Agricultural Journal 36 (9): 6-8.

PCARRD. 2003. “The Philippine Native Chickens.” In Greenfields Magazine. September 2003.p 10-11.

PCARRD 2001. "Breeding Resilient Native Chickens to Become More Productive." Animal Husbandryand Agriculture Journal 35 (5): 28-29.

PCARRD. 2000. "Improved Management of Philippine Native Chickens."

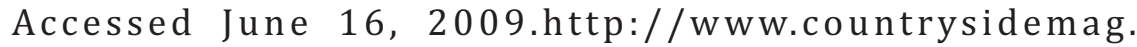
com/adv/ads.pl.

PINOY FARMER. 2008. Native Chicken Production in the Philippines.

RATANASETHAKUL, C. and B. LAOPAIBOON.1986. Improvement of native chicken raising in the Northeast 1 disease prevention and ectoparasite control. (original in Thai, English abstract).

REYNOLDS S. 1997. Integration of Animal Production in Coconut Plantations. AGP.FAO. Rome, Italy.

THOMANM W.1978. Poultry keeping in tropical areas. F.A.O. Rome. 